\title{
THE ORTHOPAEDIC IMPLICATIONS OF PERIPHERAL LIMB ISCHAEMIA IN INFANTS AND CHILDREN
}

\author{
M. J. FARRAR， G. C. BENNET, N. I. L. WILSON, A. AZMY \\ From the Royal Hospital for Sick Children, Glasgow, Scotland
}

$\mathbf{P}$ eripheral limb ischaemia is rare in children. We have treated only 12 infants and children with this condition in the past 15 years at the Royal Hospital for Sick Children in Glasgow.

There were nine neonates and three older children. Most were suffering from life-threatening illnesses or severe infection. Two were born with ischaemic arms with no apparent cause. We have analysed the factors leading to ischaemia, the outcome of the initial treatment and the later orthopaedic problems.

Two required amputation of both legs, one of an arm, two of feet and one of toes. Two had skin grafts. All surgery was performed after demarcation was well established and delayed closure was used after amputation.

Five children developed limb-length discrepancy or an angular deformity. To date two have required additional corrective surgery.

J Bone Joint Surg [Br] 1996;78-B:930-3.

Received 13 March 1996; Accepted 16 April 1996

Gangrene of the limbs is rare in children. In neonates, ischaemia of a limb leading to gangrene has been observed in association with birth asphyxia, Rhesus disease, respiratory distress, severe congenital anomalies and maternal diabetes (Urbaniak, O'Neil and Meyer 1973; Hoffmann et al 1974; Hessinger 1975; Rose and Cousino 1977; Nikolaou-Papanajotou et al 1983; Rayner, Lloyd and Ward 1984). It may also be caused by invasive vascular access (Stringel et al 1985). In older children, when it is not of traumatic origin, it is often associated with systemic infections and the syndrome of purpura fulminans may develop (Urbaniak et al 1973; Canale and Ikard 1984; Watson and

M. J. Farrar, MB, FRCS, Orthopaedic Registrar

G. C. Bennet, MB, FRCS, Consultant Orthopaedic Surgeon

N. I. L. Wilson, MB, FRCS, Consultant Orthopaedic Surgeon

A. Azmy, MB, FRCS, Consultant Paediatric Surgeon

Orthopaedic Department, The Royal Hospital for Sick Children, Yorkhill, Glasgow G3 8SJ, UK.

Correspondence should be sent to Mr G. C. Bennet.

(C)1996 British Editorial Society of Bone and Joint Surgery 0301-620X/96/61260\$2.00

Ashworth 1983; Jacobsen and Crawford 1984; Grogan et al 1989; Nogi 1989; Cohen et al 1990; Landham, Datta and Nirula 1991; Wyssa, LeCoultre and Kaelin 1992). Although severe ischaemia may necessitate amputation, a less severe insult may cause disturbance of growth.

\section{PATIENTS AND RESULTS}

Between 1977 and 1992 in the Royal Hospital for Sick Children, Glasgow we treated 12 children with limb ischaemia, with or without gangrene. Nine were neonates and three were older aged between 18 months and 5 years (Table I).

In the neonatal group the legs were most severely involved (Fig. 1). Two children required bilateral above-

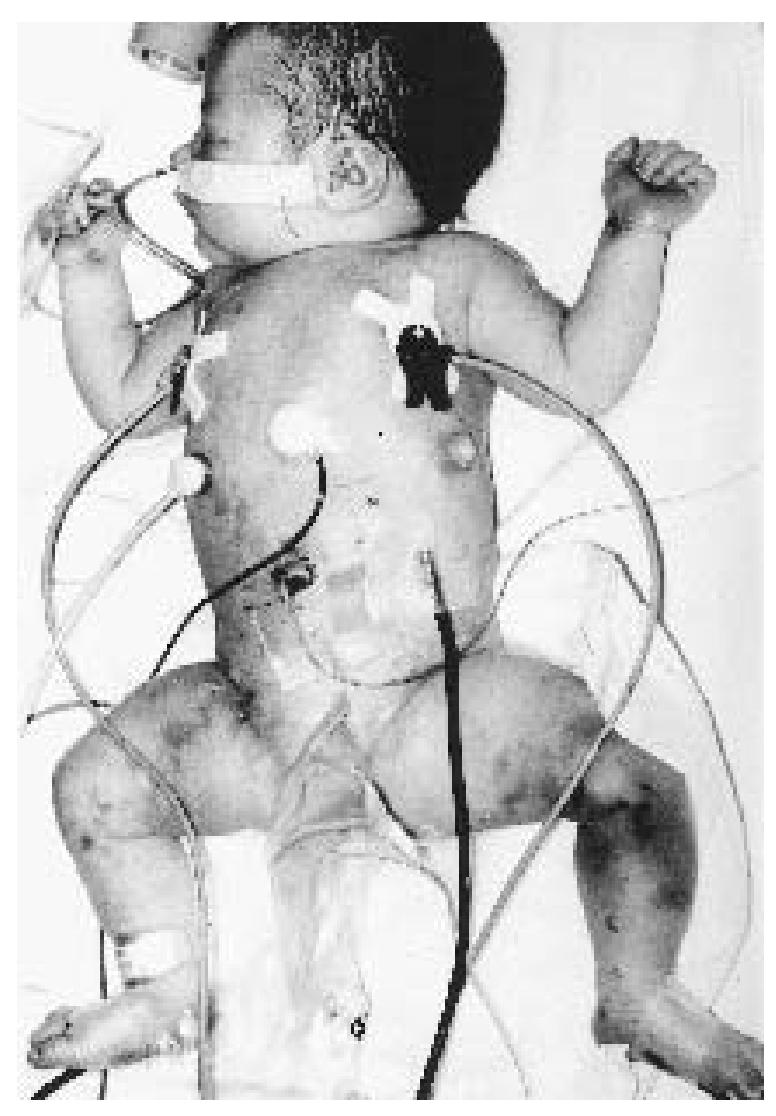

Fig. 1

A severely ill infant. Note the umbilical catheter. THE JOURNAL OF BONE AND JOINT SURGERY 


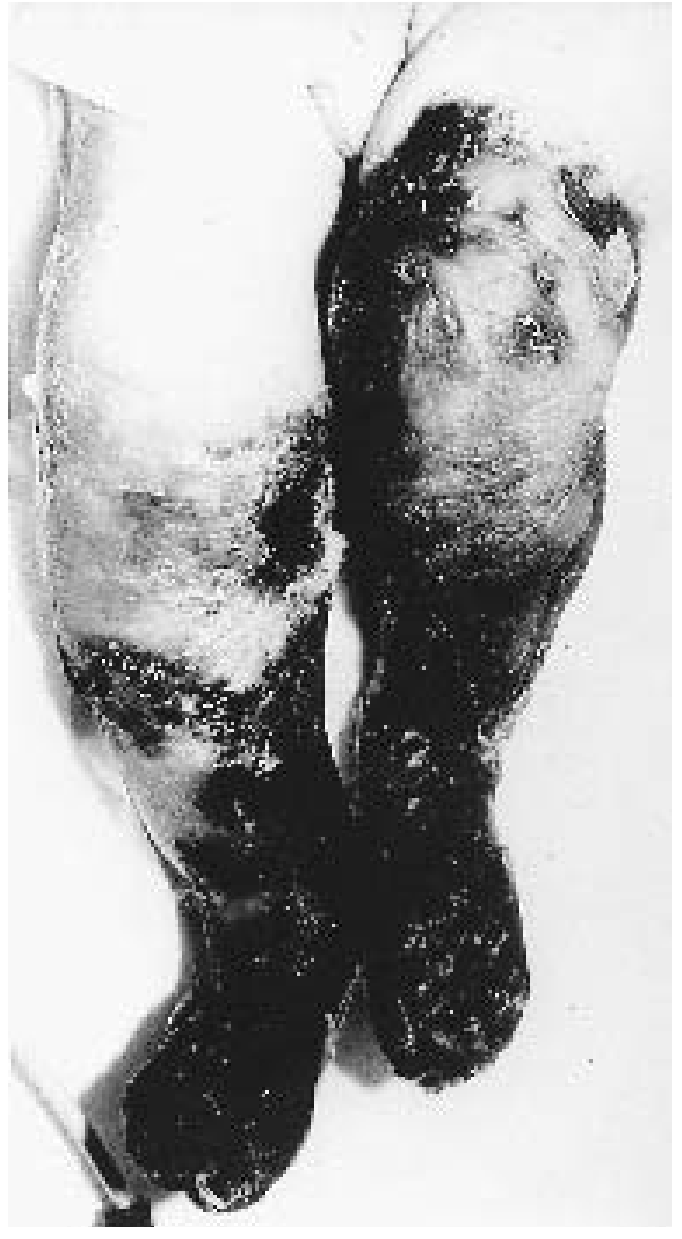

Fig. 2

Severe gangrene of both legs before bilateral amputation.

knee or below-knee amputation (Fig. 2) and one had amputations of toes. One had separation of gangrenous areas with subsequent healing and another no tissue loss. The three who did not have major amputations have subsequently developed growth disturbance, and two of them have required surgery (Fig. 3).

The condition was less severe in the four with involvement of the upper limb. One child had skin loss requiring grafting after an injection of sodium bicarbonate during resuscitation. Two had been born with an apparent ischaemic problem in the arm, one with blistering and the other with frank skin necrosis; both had primary healing but later developed limb shortening and deformity. The last child, born to a diabetic mother, developed an acutely ischaemic arm one hour after birth. With conservative treatment the ischaemia reversed and there was no subsequent limb deformity.

The three older children whom we reviewed had suffered loss of parts of limbs and all had been systemically unwell with septicaemia. In this group, no growth disturbances have been seen to date.

When amputations were performed the stumps were left

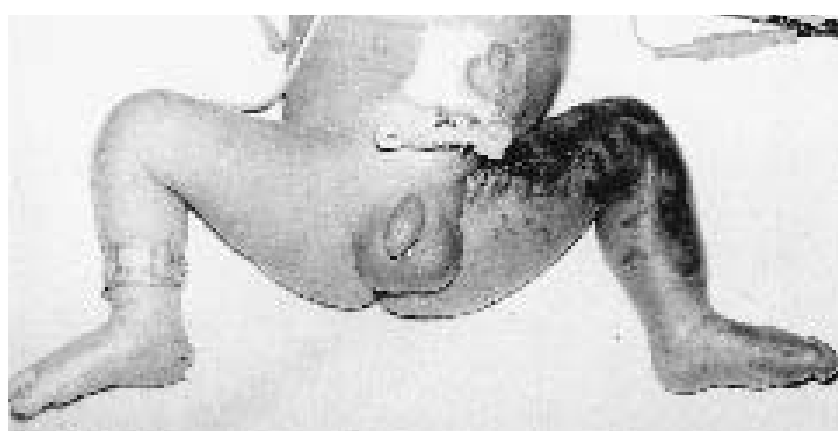

Fig. 3

Case 6. Evolving gangrene in the left leg.

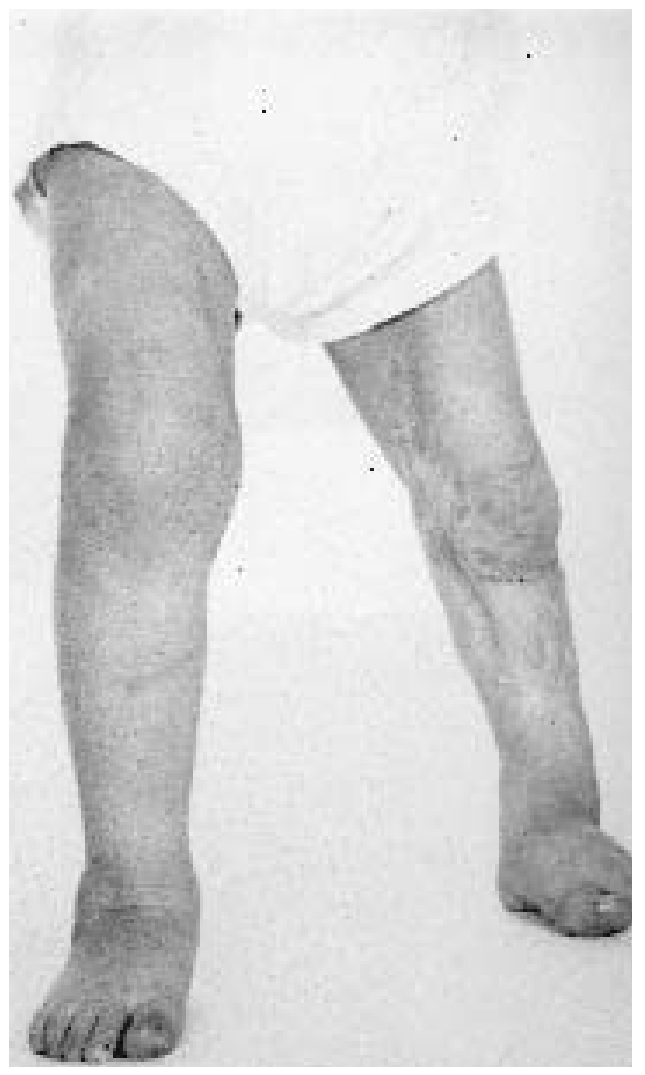

Fig. 4

Result after two corrective osteotomies for progressive varus deformity at the knee.

open for several days before secondary closure. In those who had had major amputations ongoing review was at a limb-fitting centre. In those with less severe damage orthopaedic follow-up has been continued except for two who have moved away.

Operation has been undertaken for fixed deformity. One child had two tibial osteotomies (Fig. 4) and another had lengthening of the tendo Achillis at the age of six years for persistent equinus deformity. No child with shortening has as yet required limb lengthening. 
Table I. Details of 12 patients with gangrene of the limb

\begin{tabular}{|c|c|c|c|c|c|}
\hline Case & $\begin{array}{l}\text { Age at } \\
\text { presentation }\end{array}$ & $\begin{array}{l}\text { Predisposing } \\
\text { factors }\end{array}$ & Initial outcome & Treatment & Late outcome \\
\hline 1 & Birth & None & $\begin{array}{l}\text { Necrosis of fingertips } \\
\text { and patches forearm }\end{array}$ & Allowed to separate & $\begin{array}{l}\text { Shortened forearm } \\
\text { Small hand } \\
\text { Contracture forearm muscles }\end{array}$ \\
\hline 2 & Birth & None & Resolved, no tissue loss & & $\begin{array}{l}\text { Shortened forearm } \\
\text { Small hand } \\
\text { Contracture forearm muscles }\end{array}$ \\
\hline 3 & $1 \mathrm{hr}$ & Diabetic mother & Resolved, no tissue loss & & No impairment \\
\hline 4 & 1 day & $\begin{array}{l}\text { Birth asphyxia } \\
\text { Sodium bicarbonate infusion }\end{array}$ & Patch skin necrosis & $\begin{array}{l}\text { Debridement day } 14 \\
\text { Split-skin graft day } 26\end{array}$ & $100 \%$ graft take \\
\hline 5 & $3 \mathrm{hrs}$ & $\begin{array}{l}\text { Birth asphyxia } \\
\text { Umbilical catheter }\end{array}$ & Resolved, no tissue loss & & $\begin{array}{l}1.5 \mathrm{~cm} \text { short left leg } \\
\text { Left foot drop }\end{array}$ \\
\hline 6 & $3 \mathrm{hrs}$ & $\begin{array}{l}\text { Rhesus disease } \\
\text { Exchange transfusion } \\
\text { Umbilical catheter }\end{array}$ & Necrosis at knee and toes & $\begin{array}{l}\text { Iliac embolectomy } \\
\text { Amputation of toes at day } 66\end{array}$ & $\begin{array}{l}\text { Short leg } \\
\text { Varus knee and ankle } \\
\text { Syme's amputation aged } 8\end{array}$ \\
\hline 7 & $9 \mathrm{hrs}$ & $\begin{array}{l}\text { Premature } \\
\text { Respiratory distress } \\
\text { Intermittent positive- } \\
\text { pressure ventilation } \\
\text { Coagulopathy }\end{array}$ & Gangrene of both legs & $\begin{array}{l}\text { Bilateral iliac embolectomy } \\
\text { Right above-knee amputation } \\
\text { Left below-knee amputation day } 25\end{array}$ & Good mobility with prosthesis \\
\hline 8 & 6 days & $\begin{array}{l}\text { Premature } \\
\text { Posterior tibial artery } \\
\text { cannulation }\end{array}$ & $\begin{array}{l}\text { Gangrene of skin of forefoot } \\
\text { and heel pad }\end{array}$ & Allowed to separate & $\begin{array}{l}3 \mathrm{~cm} \text { shortening lower leg } \\
20^{\circ} \text { equinus - tendo } \\
\text { Achillis lengthening - aged } 6\end{array}$ \\
\hline 9 & 31 days & $\begin{array}{l}\text { Obstructive uropathy } \\
\text { Septicaemia } \\
\text { Necrotising enterocolitis }\end{array}$ & Gangrene of both legs & $\begin{array}{l}\text { Left above-knee amputation } 28 \text { days } \\
\text { Right below-knee amputation } 50 \text { days }\end{array}$ & Died from recurrent septicaemia \\
\hline 10 & $18 \mathrm{mths}$ & $\begin{array}{l}\text { Pneumonia } \\
\text { Tracheostomy } \\
\text { Transfer from overseas }\end{array}$ & Gangrene of arm & $\begin{array}{l}\text { Brachial embolectomy } \\
\text { Below-knee amputation }\end{array}$ & \\
\hline 11 & $2 \mathrm{yrs}$ & Meningococcal septicaemia & Gangrene of fingertips & Allowed to separate & No functional deficit \\
\hline 12 & $5 \mathrm{yrs}$ & Staphylococcal septicaemia & Gangrene of both feet & $\begin{array}{l}\text { Amputation and left } \\
\text { transmetatarsal amputation }\end{array}$ & Plays football \\
\hline
\end{tabular}

\section{DISCUSSION}

Gangrene is rarely seen in children. In neonates the blood lacks clotting factors at birth, but it is hypercoagulable due to fetal fibrinogen and circulating placental thromboplastins. Intravascular coagulation can be initiated by many of the complications of neonatal life such as asphyxia, respiratory distress, infection and Rhesus disease. Occlusion of small vessels occurs and may be the cause of gangrene in such patients.

Many of the neonates had a history of invasive vascular access and in one child (case 8) this was the direct cause of the gangrene. The dangers of umbilical catheters have been studied in a series of 100 neonates who had umbilical catheterisation (Stringel et al 1985). Thirty-two had blanching of the lower limbs during infusions through the catheters and two developed gangrene. If blanching is observed the infusion must be stopped immediately.

Growth disturbance after purpura fulminans has been well reported (Watson and Ashworth 1983; Jacobsen and Crawford 1984; Grogan et al 1989; Nogi 1989; Wyssa et al 1992). In this condition circulating immune complexes activate complement on the walls of small vessels leading to intimal damage and thrombosis. If this is widespread, gangrene of a limb can occur.

In a clinical and pathological study by Grogan et al (1989) the cause of growth disturbance was shown to be thrombosis in the cartilage-canal system in the physeal plate, which causes separation of columns of chondrocytes, especially in the germinal zone, leading to arrest of growth. Areas of bone bridging may form a physical block to physeal growth.

In another study of purpura fulminans by Nogi (1989), bacteria could not be grown from either the bone or the growth plate in three patients in whom multiple sites of growth disturbance occurred. The underlying pathology is ischaemic damage to the physis and not direct infection; similar pathological changes may be the cause of growth disturbance in neonates.

After treatment of the gangrenous limb, shortening reached a maximum in the first few months and then became fixed with a normal rate of growth thereafter. This is a type-3B growth discrepancy as described by Shapiro (1982). Relatively early physeal closure may also be seen in these children; it may cause late progression of length discrepancy as in type 4 of Shapiro's classification. 


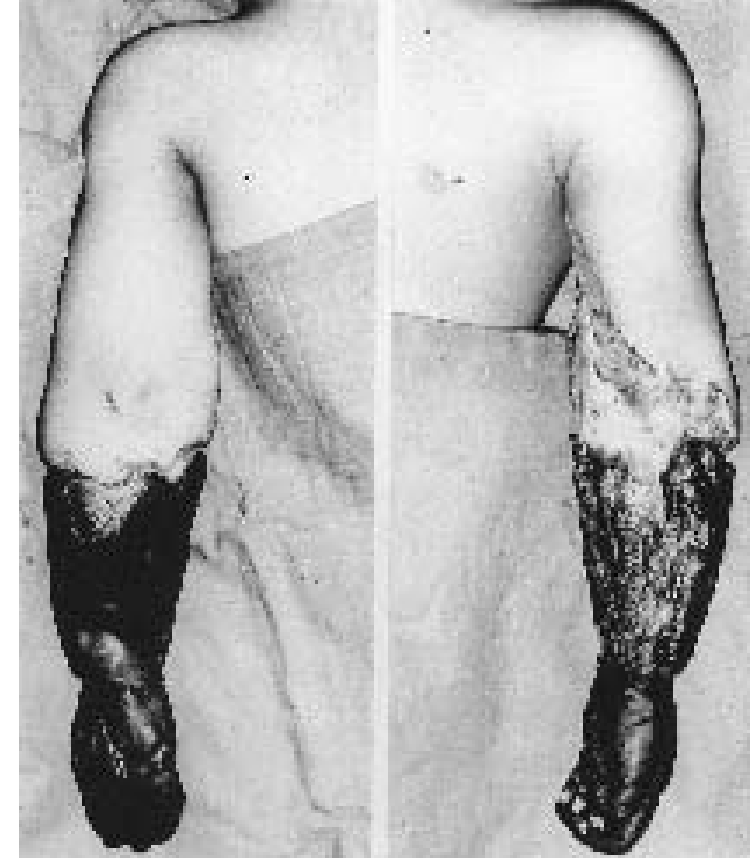

Fig. 5

Case 10. Gangrene of the forearm. Waiting for demarcation allowed a below-elbow amputation rather than the above-elbow amputation which had been anticipated.

The primary treatment required for vascular impairment is manipulation of the coagulation system. Thrombectomy or embolectomy alone was unsuccessful in every case in which it was attempted, but none had anticoagulation or thrombolytic treatment. Several studies (Urbaniak et al 1973; Nikolaou-Papanajotou et al 1983; Jacobsen and Crawford 1984; Cohen et al 1990) have shown that administration of heparin can influence progression of the gangrene and the use of postoperative, intra-arterial streptokinase has been recommended when arterial repair is performed (McFadden, Ochsner and Mills 1983). These studies have also shown the failure of steroids (Urbaniak et al 1973; Canale and Ikard 1984; Jacobsen and Crawford 1984), vasodilators (Canale and Ikard 1984) and hyperbaric oxygen (Urbaniak et al 1973; Canale and Ikard 1984; Jacobsen and Crawford 1984).

The management of a gangrenous limb is primarily conservative (Canale and Ikard 1984; Jacobsen and Crawford 1984; Rayner et al 1984; Landham et al 1991). In our patients no surgery was undertaken until the lines of demarcation had been well established. These were usually more distal than originally expected, thus preserving limb length, and, in one patient (case 10), a joint (Fig. 5). When digits are involved they should be allowed to auto-amputate.

Two studies have shown that early split skin grafting of gangrenous areas leads to failure of the graft due to the underlying tissue necrosis (Jacobsen and Crawford 1984; Wyssa et al 1992). We performed grafting after demarcation had occurred and it was successful in our patients.

No benefits in any form have been received or will be received from a commercial party related directly or indirectly to the subject of this article.

\section{REFERENCES}

Canale ST, Ikard ST. The orthopaedic implications of purpura fulminans. J Bone Joint Surg [Am] 1984;66-A:764-9.

Cohen JR, Lackner R, Keller A, Douglas B. The surgical implications of purpura fulminans. Ann Vasc Surg 1990;4:276-9.

Grogan DP, Love SM, Ogden JA, Millar EA, Johnson LO. Chondroosseous growth abnormalities after meningococcaemia: a clinical and histopathological study. J Bone Joint Surg [Am] 1989;71-A:920-8.

Hessinger RN. Gangrene of the new-born: a case report. J Bone Joint Surg [Am] 1975;57-A:121-3.

Hoffmann S, Valderrama E, Gribetz I, Strauss L. Gangrene of the hand in a new-born child. Hand 1974;6:70-3.

Jacobsen ST, Crawford AH. Amputation following meningococcaemia: a sequel to purpura fulminans. Clin Orthop 1984;185:214-9.

Landham TL, Datta D, Nirula HC. Amputation for gangrene of the limbs following severe meningococcal infection. $J R$ Coll Surg Edinb 1991;36:11-2.

McFadden PM, Ochsner JL, Mills N. Management of thrombotic complications of invasive arterial monitoring of the upper extremity. J Cardiovasc Surg 1983;24:35-9.

Nikolaou-Papanajotou, Fuchs F, von Voss H, Göbel U. Acute disturbance of peripheral circulation with gangrene in infancy (abstract). Klin Padiatr 1983;195:57-9.

Nogi J. Physeal arrest in purpura fulminans: a report of three cases. J Bone Joint Surg [Am] 1989;71-A:929-31.

Rayner CR, Lloyd DJ, Ward K. Neonatal upper limb ischaemia: the case for conservative management. J Hand Surg [Br] 1984;9:57-8.

Rose E, Cousino V. A case of acute ischaemia of the extremities in disseminated intravascular coagulation in an infant (abstract). Ann Anesthesiol Fr 1977;18:291-4.

Shapiro F. Developmental patterns in lower extremity length discrepancies. J Bone Joint Surg [Am] 1982;64-A:639-51.

Stringel G, Mercer S, Richler M, McMurray B. Catheterisation of the umbilical artery in neonates: surgical implications. Can J Surg 1985; 28:143-6.

Urbaniak JR, O'Neil MT, Meyer LC. Purpura fulminans. J Bone Joint Surg [Am] 1973;55-A:69-77.

Watson CH, Ashworth MA. Growth disturbance and meningococcal septicemia: report of two cases. J Bone Joint Surg [Am] 1983;65-A: 1181-3.

Wyssa B, LeCoultre C, Kaelin A. Orthopaedic and surgical implications of meningococcaemia. J Paediatr Orthop, part B 1992;1:73-7. 